\title{
Paideusis
}

\section{"The Ethical Teacher" (Elizabeth Campbell)}

\section{William Hare}

Volume 15, Number 1, 2006

URI: https://id.erudit.org/iderudit/1072698ar

DOI: https://doi.org/10.7202/1072698ar

See table of contents

Publisher(s)

Canadian Philosophy of Education Society

ISSN

0838-4517 (print)

1916-0348 (digital)

Explore this journal

Cite this review

Hare, W. (2006). Review of ["The Ethical Teacher" (Elizabeth Campbell)].

Paideusis, 15(1), 103-106. https://doi.org/10.7202/1072698ar

This document is protected by copyright law. Use of the services of Erudit (including reproduction) is subject to its terms and conditions, which can be viewed online.

https://apropos.erudit.org/en/users/policy-on-use/
This article is disseminated and preserved by Érudit.

Érudit is a non-profit inter-university consortium of the Université de Montréal, Université Laval, and the Université du Québec à Montréal. Its mission is to promote and disseminate research.

https://www.erudit.org/en/ 


\title{
Review of
}

\section{The Ethical Teacher}

by Elizabeth Campbell, Maidenhead, UK: Open University Press, 2003

\author{
WILLIAM HARE \\ Mount St. Vincent University
}

\section{Towards Ethical Awareness in Teaching}

This book is a useful contribution to the growing literature on the moral dimensions of teaching, setting out to make ethical knowledge much more visible and valued in the professional lives of teachers. An extreme form of relativism that undermines all confidence in universal ethical principles such as truthfulness, respect, and fairness is rejected; but pluralism and fallibilism with respect to the interpretation and application of ethical principles is acknowledged, and the great uncertainty and confusion that surrounds many ethical issues is a constant theme. The primary aim is not to persuade irresponsible and unethical teachers to adopt the moral point of view, but rather to help good teachers recognize and address the ethical challenges they will inevitably meet by heightening their own level of ethical understanding. There are places where the author falls short of the good judgment which is generally characteristic of her work, but any teacher who takes seriously the ethical aspects of teaching will find much of value in this book;

Part 1 deals with teaching as a moral practice, and with the teacher as an ethical person inevitably involved in moral education. Adopting the view that any action a teacher takes can have moral import, Campbell shows how easy it is to miss the ethical significance of an action when something is seen as routine and trivial, or when we come to think of teaching exclusively in terms of efficiency and time management. Like many teachers, her own moment of consciousness-raising occurred on suddenly noticing an aspect of a situation that had been hidden, in her case the fact that a student survey being administered was by no means as benign as it appeared (p. xv). Campbell draws our attention to the way in which, for example, returning student work in a timely fashion is not just a matter of being well organized but equally a matter of respect and care (p. 22); this and other examples remind us that there is an important way of interpreting and viewing a teacher's work that all too often goes unrecognized.

The point is central, and the failure in question happens even when one might think that the ethical dimension would be glaringly obvious. For example, during the Malcolm Ross case in New Brunswick, the school board in question articulated its concern in terms of being hindered in its attempts to "effectively manage and direct" the educational process, as if the problem were technical rather than ethical. Similarly, during the notorious Keegstra case in Alberta, some refused to make a judgment about Keegstra's teaching on the grounds that they were not social studies experts, thereby missing the point that there were serious ethical problems here whose recognition did not require technical expertise or specialized knowledge. These are dramatic examples of ethical blindness, but they underscore Campbell's point. If the ethical dimension of these cases is invisible, how much more so the cases which concern mundane behaviour. This book does much to draw the ethical overtones of everyday teaching out into the open.

(C) Copyright 2006. The author, William Hare, assigns to Paideusis the right of first publication and educational and non-profit institutions a non-exclusive license to use this document for personal use and in courses of instruction provided that the article is used in full and this copyright statement is reproduced. Any other usage is probibited without the express permission of the author. 
The ethical teacher, Campbell argues, is first and foremost an ethical person, someone in whom such central moral virtues as fairness, respect, trustworthiness, honesty, and kindness, have become settled dispositions which reveal themselves in the teacher's every interaction with students and constitute the very manner in which he or she teaches. Her discussion of the teacher as a moral person is, in effect, a vivid illustration of Dewey's point in How We Think (ch. 4) that "everything the teacher does, as well as the manner in which he does it, incites the child to respond in some way or other, and tends to set the child's attitude in some way or other".

The general virtues of everyday life often transfer to the teaching context instinctively and spontaneously, of course, but often too such transfer will require professional knowledge combined with teaching experience. It will also be vital for the teacher to have a conscious grasp of relevant principles as well as an awareness of the tensions and complexities inherent in their application to particular contexts. Campbell shows how the ability to articulate and justify one's ethical principles can lead to a level of moral awareness concerning ethical complexities that might otherwise remain concealed. There are no guarantees or short cuts here. The ongoing refinement of one's ethical insight must be a part of lifelong learning if ethical knowledge is to be attained, and this book will be a very useful resource for teachers to draw on.

One major strength is the continual reference to concrete cases and situations from classrooms. With reference to the teacher as moral educator, for example, Campbell illustrates the ethical minefields embedded in certain approaches adopted by teachers who aim to promote the acquisition of moral virtues in their students. Unexpectedly, their intentions are confounded by certain implications of their pedagogical strategies and well-meaning solutions. Bringing a problem to a talking circle, for example, has a positive effect on the students who caused the problem; but the student who was affected finds the public discussion a further humiliation (p. 57). The ethical teacher needs a finely-honed sense of judgment to assess the ramifications of proposed actions, and needs to steer a careful path between such extremes as being coldly impersonal and inappropriately frank with respect to one's personal life. These general truths take on a richer and more meaningful quality when seen in the light of well-chosen examples.

In Part 2, dealing with challenges to ethical professionalism, Campbell examines the particular situations that thwart a teacher's attempts to meet a high standard of ethical conduct. Teachers put under pressure to give passing grades to mediocre student teachers, schools moving students to different sections of courses to accommodate parental bigotry, zero tolerance policies that ignore crucial aspects of particular cases, all this, and much more, ultimately undermines a teacher's sense of his or her own moral agency and generates a debilitating cynicism and moral uncertainty, further fuelled by a pervasive relativism. The ability to recognize and resolve an ethical issue begins to falter and the result is what Whitehead calls that fading of ideals which constitutes a defeat for our fondest hopes. Teachers are then ill-prepared to find the confidence to develop an ethical stance with respect to controversial topics that arise in their own classrooms.

Campbell's own advice to teachers in this context is to refrain from stating their own views with respect to issues that are truly controversial (p. 81). First, however, this general recommendation would surely have to be tempered if the students in question are young adults in the final years of high school. Second, Campbell defends her advice on the grounds that stating one's view is a short step from promoting it; but this is a slippery slope argument and no reason is offered to support the view that the step cannot be resisted. Third, the vital distinction between stating and promoting one's views on controversial matters is blurred when Campbell speaks ambiguously of ideologues "airing" their views in the classroom. That word also means, perhaps even more commonly suggests, merely stating one's opinion, and this manages to make the slope seem very slippery indeed.

On another matter concerning controversial issues, Campbell refers to the recent case in British Columbia concerning the use of storybooks depicting same-sex families, and remarks that she finds the teacher's complaint that certain parents were trying to impose their views on others ironic because the complaint can in turn be made against the teacher (p. 153). What Campbell fails to say here, however, is 
that the teacher is taking the ethically justifiable view that children from all families should see themselves represented in their storybooks. As she points out in connection with other cases, not all views deserve equal time, and what needs to be said in this situation is that prejudice against sexual orientation should not be accommodated in curriculum decisions.

A sense of one's moral agency is also undermined, Campbell argues, by issues relating to one's colleagues when teachers find themselves torn between the deeply entrenched cultural norm of loyalty to fellow professionals and the need to speak out about ethical wrongdoing. The Keegstra case brought to national attention the way in which professional colleagues and teacher association officials failed to take a strong ethical stand against bigotry, no doubt persuaded otherwise by a misguided sense of loyalty. One would have hoped that some lessons would have been learned, but certain recent cases cited by Campbell, which seem to suggest solidarity at all costs, leave one wondering if the conclusion should be ils n'ont rien appris, ni rien oublié.

There is much in this section about professional autonomy being eroded by union pressure, but the account comes across as one-sided. There is no discussion of the ethical ramifications of teachers continuing to accept working conditions and school board demands that militate against students receiving a worthwhile education. One finds, for example, no hint of the point captured by Elizabeth Edwards some years ago in the title of her article, "The dedicated teacher is the teaching profession's greatest enemy"; nor is attention given to the way in which the collective voice reflected in a union or association can more confidently name ethical issues and help find the courage to address them. Campbell asserts that "unionization and the normative attitudes and initiatives that flow from it" constitute the greatest obstacle to ethical professionalism. But the problem clearly lies with the attitudes and practices alluded to, not with unionization itself, unless she intends to claim implausibly that such attitudes and practices in question are simply inseparable from unionization.

Part 3 turns to consider ways in which the problems and dilemmas might be addressed and what prospects there might be for enhancing ethical professionalism. Campbell is rather skeptical of the value of codes of ethics for teachers, partly because so many are seriously deficient, partly because formalized principles are rarely useful in concrete cases, but mainly because moral principles need to be first and foremost a living force in the teacher's ethical consciousness. More promising, Campbell believes, are school-based initiatives, such as open forum discussions, school ethics committees, and ethical leadership exemplified by principals, which may provide the opportunity and the encouragement for teachers to develop a keen sense of their own moral agency. Campbell argues for the importance of collaborative community building among teachers so that a widely shared set of ethical values will become part of the school's general culture and an indispensable part of professional renewal.

Certainly the kind of code Campbell mentions, such as that issued by the British Columbia Teachers' Federation, invites derision, but there are better codes and some references here would have been helpful. For example, the code of ethics for teachers in Queensland (http://www.btr.qld.edu.au/ reg_eth.htm) is thoughtful and thought-provoking, and provides many illustrations of specific principles. Until we have looked at the best examples of such codes, and considered ways in which they might enhance ethical knowledge, it is premature to conclude that codes of ethics for teachers are of dubious value. They may well give valuable support to other initiatives.

Campbell recognizes that many teachers who have great integrity nevertheless fail to see how their own ethical values might translate into professional practice and how they can contribute to the formation of an ethical community; and this problem naturally suggests the concluding topic of ethical professionalism in preservice and inservice teacher education programs. Here Campbell argues for greater attention to moral issues in every aspect of such programs, and my own experience suggests that this book offers encouragement to a movement already underway towards a more serious engagement with ethics in teacher education.

On the particular matter of using case studies to foster ethical awareness among teachers and student teachers, Campbell is somewhat cautious because the focus may be on weighty moral dilemmas rather than on those everyday aspects of teaching which call for ethical insight. The resolution surely 
lies in the selection of cases which deal with ordinary, everyday moments which suddenly introduce an unexpected but important ethical issue. There is ample material in the literature to draw on. A useful list of suggestions and reminders is offered by way of conclusion which serves to highlight and summarize some of the main themes developed in the book and which will prompt teachers to ask themselves the kinds of questions that give recognition and prominence to ethical concerns. Inevitably, in the area of ethics and moral education, there will be disagreement with particular advice and points of view put forward, but such disagreement can stimulate a critical and open-minded perspective. The Ethical Teacher makes a significant contribution to consciousness-raising with respect to the ethical dimensions of teaching, and such awareness is a precondition of good judgment on the part of teachers. 